\title{
ANALISIS PENYELESAIAN SISWA PADA SOAL PERSAMAAN TRIGONOMETRI DI KELAS XI MIPA SMA NEGERI 5 MODEL PALU
}

\author{
Aswan ${ }^{1)}$, Gandung Sugita ${ }^{2)}$ \\ aswanscoutsevenblong19@gmail.com ${ }^{1}$, gandungpplw@gmail.com ${ }^{2)}$
}

\begin{abstract}
Abstrak : Tujuan dari penelitian ini yaitu mendeskripsikan penyelesaian siswa pada soal persamaan trigonometri di kelas XI MIPA SMA Negeri 5 Model Palu. Jenis penelitian ini adalah penelitian kualitatif. Subjek dalam penelitian ini adalah 3 siswa yang diambil dari 30 siswa kelas XI MIPA 5. Masing-masing 1 siswa berkemampuan matematika tinggi, 1 siswa berkemampuan matematika sedang dan 1 siswa berkemampuan matematika rendah. Hasil penelitian ini menunjukkan bahwa siswa berkemampuan matematika tinggi mampu menuliskan dan menjelaskan informasi yang diperoleh dari soal dengan benar, menggunakan prosedur yang tepat dalam mengubah persamaan trigonometri, mampu mengaitkan konsep persamaan trigonometri dengan konsep lainnya yaitu nilai sudut istimewa, menentukan nilai $\alpha$ dari suatu persamaan trigonometri dan disubstitusi kerumus, menggunakan operasi aljabar berupa perkalian, pembagian dan penjumlahan dengan benar dan mampu menentukan solusi dari persamaan trigonometri pada soal yang diberikan dengan memperhatikan syarat yang diberikan pada soal. Kesalahan yang dilakukan oleh subjek berkemampuan tinggi adalah kesalahan prosedur tidak tepat (IP). Selanjutnya, siswa berkemampuan matematika sedang mampu menuliskan dan menjelaskan informasi yang diperoleh dari soal dengan benar, menggunakan prosedur yang tepat dalam mengubah persamaan trigonometri, mengaitkan konsep persamaan trigonometri dengan konsep lainnya yaitu nilai sudut istimewa. Tetapi pada proses penyelesaian soal, siswa melakukan kesalahan hirarki keterampilan (SHP), kesalahan prosedur tidak tepat (IP) dan kesalahan data tidak tepat (ID). Sedangkan siswa berkemampuan matematika rendah mampu menjelaskan informasi yang diperoleh dari soal dengan benar dan menggunakan prosedur yang tepat dalam mengubah persamaan trigonometri. Tetapi pada proses penyelesaian soal, siswa melakukan kesalahan hirarki keterampilan (SHP), kesalahan prosedur tidak tepat (IP), kesalahan konflik level respon (RLC) dan kesalahan kesimpulan hilang (OC).
\end{abstract}

Kata kunci : analisis, penyelesaian, persamaan, trigonometri, kesalahan, watson.

Matematika merupakan pengetahuan yang memiliki peranan penting dalam kehidupan sehari-hari serta menjadi pengetahuan yang mendasari perkembangan ilmu pengetahuan dan teknologi. Mengingat pentingnya peranan matematika, maka matematika perlu diajarkan diseluruh jenjang pendidikan mulai dari pendidikan usia dini hingga perguruan tinggi.

Satu diantara materi yang diajarkan pada matapelajaran matematika kelas XI dalam kurikulum tahun 2013 (K13) adalah trigonometri. Sudarsono (2017) mengatakan bahwa faktor penyebab kesulitan yang dialami oleh siswa dalam menyelesaikan soal-soal trigonometri yaitu kesulitan dalam menerapkan konsep dan menggunakan prosedur yang tepat. Selain itu, hasil penelitian yang dilakukan oleh Mahmudah (2018) di kelas XI MAN 2 Tulungagung bahwa siswa dengan kemampuan matematika tinggi, sedang dan rendah memiliki kemampuan yang berbeda menggunakan konsep dan prosedur dalam menyelesaikan soal matematika.

Kemampuan berbeda-beda yang dimiliki siswa dalam menyelesaikan soal trigonometri diduga dimiliki juga oleh siswa kelas XI SMA Negeri 5 Model Palu. Oleh karena itu, peneliti melakukan pengamatan terhadap proses pembelajaran matematika di kelas XI MIPA SMA Negeri 5 Model Palu. Ada siswa yang mampu menyelesaikan soal dengan benar tetapi masih ada siswa yang melakukan kesalahan dalam menyelesaikannya. Menindaklanjuti hal tersebut, maka calon peneliti melakukan dialog dengan seorang guru matematika di SMA Negeri 5 Model Palu. Berdasarkan informasi yang diperoleh bahwa kemampuan siswa dalam menyelesaikan soal persamaan trigonometri berbeda-beda. Ada siswa yang menunjukkan kemampuan yang sangat baik dalam menerapkan materi yang telah diajarkan oleh guru dalam menyelesaikan soal. Namun, masih terdapat siswa yang mengalami kesulitan dalam menyelesaikan soal.

Peneliti merasa perlu dilakukan analisis terhadap penyelesaian soal siswa dikarenakan adanya perbedaan kemampuan siswa dalam menerapkan materi yang telah diajarkan oleh guru serta masih terdapat kesalahan yang dilakukan oleh siswa dalam menyelesaikan soal. Hasil analisis dapat dijadikan sebagai bahan referensi yang memberikan informasi mengenai kelemahan siswa dalam menerapkan materi persamaan trigonometri yang telah diajarkan. Jika terdapat kesalahan dalam penyelesaian maka perlu diidentifikasi jenis-jenis kesalahan yang dilakukan oleh siswa. Sehingga guru dapat merancang rencana pembelajaran berdasarkan kelemahan 
siswa sehingga dalam kemampuan siswa dalam menyelesaikan soal semakin baik dan hasil belajar dapat meningkat. Hal ini sejalan dengan yang dikemukakan oleh Kramarski dan Zoldan (2008) bahwa dengan menganalisis jawaban yang benar dan kesalahan konseptual siswa dapat menjadi dasar untuk memperbaiki pemahaman dan penguasaan materi siswa.

Berdasarkan uraian tersebut, maka peneliti mengajukan sebuah judul penelitian Analisis Penyelesaian Siswa pada Soal Persamaan Trigonometri di Kelas XI MIPA SMA Negeri 5 Model Palu.

\section{METODE PENELITIAN}

Penelitian ini merupakan penelitian kualitatif yang mendeskripsikan data yang diperoleh berupa uraian kata-kata tertulis maupun lisan yang berasal dari subjek penelitian. Subjek penelitian ini adalah siswa kelas XI MIPA SMA Negeri 5 Model Palu tahun ajaran 2019/2020. Banyak subjek yang dipilih adalah tiga siswa yang terdiri masing-masing satu siswa yang berkampuan matematika tinggi, sedang dan rendah. Pemilihan subjek dilakukan dengan melihat nilai ujian semester siswa, kesedian siswa menjadi subjek penelitian dan kemampuan siswa untuk berkomunikasi dan mengungkapkan pendapat atau jalan pikirannya baik secara lisan maupun tulisan sesuai rekomendasi dari guru matapelajaran matematika.

Instrumen utama dalam penelitian ini adalah peneliti sendiri. Metode pengumpulan data yang digunakan dalam penelitian ini adalah metode tes dan wawancara. Data dalam penelitian ini divalidasi menggunakan triangulasi waktu. Triangulasi waktu dilakukan dengan membandingkan data hasil tes dan wawancara tahap 1 dengan data hasil tes dan wawancara tahap 2. Analisis data yang digunakan mengacu pada analisis data menurut Miles dan Huberman dalam Sugiyono (2018) yakni kondensasi data, penyajian data, dan penarikan kesimpulan.

\section{HASIL PENELITIAN}

Berdasarkan pengolahan data nilai semester siswa kelas XI MIPA 5 SMA Negeri 5 Model Palu maka dilakukan pengelompokkan siswa berdasarkan tingkat kemampuan matematika. Setelah dilakukan pengelompokkan kategori kemampuan matematika siswa, selanjutnya dipilih satu subjek yang masing-masing mewakili kelompok kategori siswa berkemampuan matematika tinggi, berkemampuan matematika sedang dan berkemampuan matematika rendah. Subjek dengan kategori berkemampuan matematika tinggi yaitu MA. Subjek dengan kategori berkemampuan matematika sedang yaitu CR. Subjek dengan kategori berkemampuan matematika rendah yaitu MAG.

Setelah terpilih tiga orang subjek penelitian, selanjutnya masing-masing subjek mengerjakan soal persamaan trigonometri yang telah disiapkan oleh peneliti. Kemudian peneliti melaksanakan wawancara dengan masing-masing subjek penelitian berdasarkan hasil tes tertulis. Pemberian tes tertulis dan wawancara tahap 1 dilaksanakan pada tanggal 20 Juli 2020. Untuk menguji kredibilitas data yang diperoleh pada pelaksanaan tes dan wawancara yang pertama, dilakukan pemberian tes tertulis dan wawancara tahap kedua pada tanggal 22 Juli 2020. Oleh karena data setiap subjek kredibel maka analisis penyelesaian soal setiap subjek dapat menggunakan data pada hasil tes tertulis dan wawancara tahap 1 atau tahap 2. Pada penelitian ini, peneliti menggunakan data setiap subjek dalam menyelesaikan soal pada tahap 1 . 
Analisis penyelesaian soal subjek berkemampuan matematika tinggi

Hasil tes tertulis ST dalam menyelesaikan S1 dipaparkan sebagaimana Gambar 1:

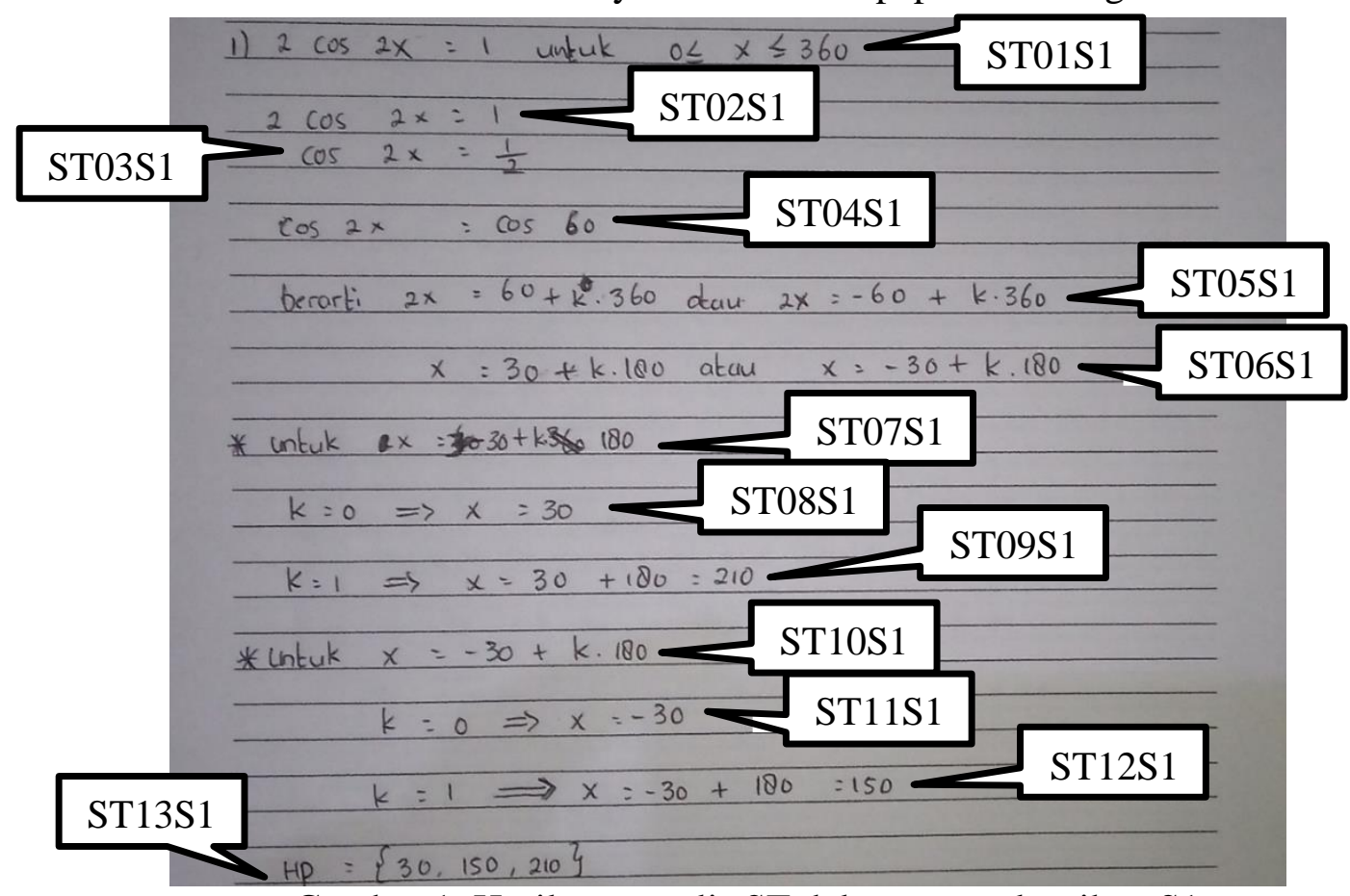

Gambar 1. Hasil tes tertulis ST dalam menyelesaikan S1

Penyelesaian ST terhadap S1 dapat dilihat sebagaimana Gambar 1, ST menyelesaikan S1 dengan menuliskan hal-hal yang diketahui (ST01S1). Kemudian ST menuliskan persamaan $2 \cos 2 x=1$ (ST02S1). Selanjutnya ST membagi masing-masing ruas dengan 2 sehingga diperoleh $\cos 2 x=\frac{1}{2}$ (ST03S1). Selanjutnya ST mengubah ruas kanan yaitu $\frac{1}{2}$ menjadi cos 60 sehingga diperoleh $\cos 2 x=\cos 60$ (ST04S1). Kemudian ST menyelesaikan $\cos 2 x=\cos 60$ dengan menggunakan rumus $2 x=60+k .360$ atau $2 x=-60+k .360$ (ST05S1). Selanjutnya ST membagi masing-masing ruas pada rumus tersebut dengan 2 sehingga diperoleh $\mathrm{x}=30+\mathrm{k} .180$ atau $\mathrm{x}=-30+\mathrm{k} .180$ (ST06S1). Kemudian ST mensubtitusi nilai k kerumus untuk memperoleh nilai x. Selanjutnya ST menuliskan himpunan penyelesaiannya yaitu $\{30,150,210\}$ (ST13S1).

Peneliti melakukan wawancara dengan ST untuk memperoleh informasi lebih lanjut mengenai penyelesaian ST pada S1. Adapun petikan wawancara sebagai berikut:

PN1005S1 : Setelah membaca soal itu, informasi apa yang ade dapatkan?

ST1006S1 : Yang saya dapat itu, persamaan $2 \cos 2 x=1$ untuk $0 \leq x \leq 360$.

PN1007S1 : Apakah hanya informasi itu yang kamu dapatkan?

ST1008S1 : Masih ada kak, yang ditanyakan itu himpunan penyelesaiannya.

PN1009S1 : Coba jelaskan jawaban yang ade peroleh.

ST1010S1 : Pertama saya tuliskan ulang soalnya kak, $2 \cos 2 x=1$, untuk $0 \leq x \leq 360$.

ST1012S1 : Selanjutnya 1 itu saya bagi dengan 2 kak supaya bentuknya jadi persamaan cos.

ST1014S1 : Yang cos $\mathrm{x}=$ a kak.

ST1022S1 : Supaya persamaannya itu kak jadi persamaan $\cos x=\cos \alpha$. Jadi ${ }^{1} \underset{2}{\text { itu saya }}$ ubah jadi cos 60 .

ST1024S1 : Karena cos $60=\frac{1}{2}$ kak.

PN1027S1 : Setelah diperoleh $\cos 2 \mathrm{x}=\cos 60$, apa langkah selanjutnya?

ST1028S1 : Saya masukkan nilai $\alpha$ nya kerumus untuk mencari nilai x untuk persamaan cos kak. 
PN1029S1 : Berapa nilai $\alpha$ nya?

ST1030S1 : 60 kak.

PN1031S1 : Diperoleh dari mana nilai $\alpha=60 \mathrm{itu}$ ?

ST1032S1 : Dari $\cos 2 \mathrm{x}=\cos 60 \mathrm{kak}$, jadi $\alpha$ nya itu $60 \mathrm{kak}$

PN1033S1 : Tapi kenapa di lembar jawaban tidak ade tuliskan nilai $\alpha$ nya?

ST1034S1 : Iya kak. Tidak ada saya tulis. Langsung saya masukkan kerumus saja nilai $\alpha$ nya.

ST1038S1 : Rumusnya $\mathrm{x}=\alpha+\mathrm{k} 360$ atau $\mathrm{x}=-\alpha+\mathrm{k} 360$.

PN1039S1 : Terus apa langkah selanjutnya?

ST1040S1 : Saya masukkan nilai $\alpha$ nya. Jadi diperoleh $2 \mathrm{x}=60+\mathrm{k} .360$ atau 2x $=-60+\mathrm{k} .360$ kak. Terus saya sederhanakan kak. Diperoleh $\mathrm{x}=30+$ $\mathrm{k} .180$ atau $\mathrm{x}=-30+\mathrm{k} .180$.

PN1041S1 : Setelah itu, bagaimana cara ade memperoleh nilai $x$ nya?

ST1042S1 : Saya selesaikan dulu persamaan yang $\mathrm{x}=30+\mathrm{k} .180$. Saya ganti nilai $\mathrm{k}=0$, saya dapat nilai $\mathrm{x}$ nya 30 . Terus saya ganti nilai $\mathrm{k}=1$, saya dapat nilai $\mathrm{x}$ nya 210 kak.

ST1044S1 : Karena k itu bilangan bulat kan kak. Jadi saya ganti dengan 0 dulu, setelah itu 1. Terus dilihat yang memenuhi.

ST1046S1 : Memenuhi syaratnya kak. kan syaratnya $0 \leq x \leq 360$.

PN1051S1 : Setelah itu, apa lagi yang kau lakukan?

ST1052S1 : Saya cari lagi nilai $x$ yang memenuhi untuk persamaan $\mathrm{x}=-30+\mathrm{k} .180 \mathrm{kak}$.

ST1054S1 : Saya misalkan lagi $\mathrm{k}=0$ diperoleh $\mathrm{x}$ nya -30 , terus untuk $\mathrm{k}=1$ diperoleh $\mathrm{x}$ nya 150.

PN1059S1 : Jadi apa himpunan penyelesaiannya?

ST1060S1 : Himpunan penyelesaiannya 30, 150 dan 210 kak.

Adapun hasil wawancara menunjukkan bahwa ST mampu menjelaskan secara lisan halhal yang diketahui dan ditanyakan pada soal. Kemudian ST menjelaskan alasan mengubał $\frac{1}{2}$ menjadi $\cos 60$ yaitu agar persamaan trigonometri bentuk $\cos \mathrm{x}=$ a menjadi bentuk $\cos \mathrm{x}=\cos \alpha$. Berdasarkan hasil wawancara menunjukkan bahwa ST menyelesaikan soal dengan menentukan nilai $\alpha$ dari persamaan $\cos 2 x=\cos 60$ (ST04S1). Kemudian untuk memperoleh himpunan penyelesaian dari persamaan trigonometri pada soal, ST mensubstitusi nilai $\alpha$ kerumus $x=\alpha+$ k. 360 atau $x=-\alpha+k$. 360. Dalam menyelesaikan soal, ST tidak menuliskan secara rinci proses penyelesaiannya tetapi langsung menuliskan hasil dari mensubstitusi nilai k kerumus. Namun, ST melakukan kesalahan dalam memilih nilai k karena tidak mengambil nilai yang memenuhi yaitu $\mathrm{k}=2$ untuk disubtitusi kerumus $x=-\alpha+k .360$.

Hasil tes tertulis ST dalam menyelesaikan S2 dipaparkan sebagaimana Gambar 2:

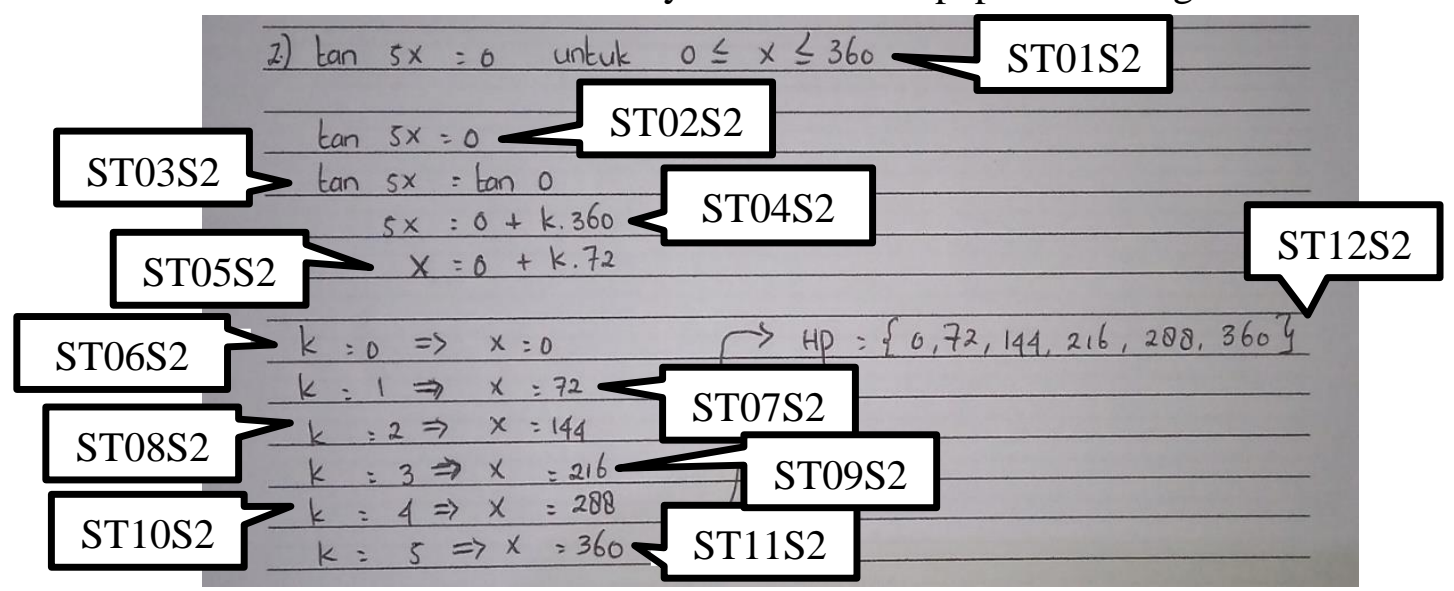

Gambar 2. Hasil tes tertulis ST dalam menyelesaikan S2 
Penyelesaian ST terhadap S2 dapat dilihat sebagaimana Gambar 2. ST menjawab soal dengan menuliskan tan $5 x=0$ untuk $0 \leq x \leq 360$ (ST01S2). Kemudian ST menuliskan kembali persamaan tan $5 x=0$ (ST02S2). Selanjunya ST mengubah ruas kanan menjadi tan 0 sehingga diperoleh persamaan $\tan 5 x=\tan 0$ (ST03S2). Kemudian ST menyelesaikan persamaan $\tan 5 x=\tan 0$ menggunakan rumus $5 x=0+\mathrm{k} .360$ (ST04S2). ST menyederhanakan rumus tersebut dengan membagi masing-masing ruas dengan 5 sehingga diperoleh $\mathrm{x}=0+\mathrm{k} .72$ (ST05S2). Kemudian ST mensubtitusi nilai k kerumus untuk memperoleh nilai $x$. Selanjutnya ST menentukan himpunan penyelesaiannya yaitu $\{0,72$, 144, 216, 288, 360\} (ST12S2).

Peneliti melakukan wawancara dengan ST untuk memperoleh informasi lebih lanjut mengenai penyelesaian ST pada S2. Adapun petikan wawancara sebagai berikut:
PN1005S2
Bagaimana cara ade mencari himpunan
penyelesaianya? ST1006S2 : Pertama saya tulis ulang
dulu soalnya $\tan 5 \mathrm{x}=0 \mathrm{kak}$.
PN1007S2 : Setelah itu?
ST1008S2 : Saya ubah sebelah kanannya kak. 0 menjadi tan 0.
ST1010S2 : Supaya jadi bentuk persamaan $\tan \mathrm{x}=\tan \alpha$ kak. PN1011S2 : Kenapa diubah jadi $\tan 0$ ?
ST1012S2 : Karena $0=\tan 0$ kak.
PN1013S2 : Dari mana didapat $0=\tan 0$ ?
ST1014S2 : Dari nilai sudut istimewa kak.
PN1015S2 : Setelah diperoleh $\tan 2 \mathrm{x}=\tan 0$, apa langkah selanjutnya?
ST1016S2 : Sama seperti soal nomor 1 kak, kan sudah didapat nilai $\alpha$ nya 0 jadi saya masukkan nilai $\alpha$ itu kerumus mencari nilai x untuk tan kak.
PN1017S2 : Yang bagaimana rumusnya?
ST1018S2 : $\mathrm{x}=\alpha+\mathrm{k} .360 \mathrm{kak}$.
PN1021S2 : Jadi setelah ade masukkan nilai $\alpha$ nya kerumus, apa langkah selanjutnya?
ST1022S2 : Saya peroleh $5 \mathrm{x}=0+$ k.360.
PN1023S2 : Setelah itu?
ST1024S2 : Saya sederhanakan persamaannya kak, saya bagi dengan 5.
ST1030S2 : Kan sudah saya dapat persamaannya $\mathrm{x}=0+\mathrm{k} .72$. Jadi saya misalkan $\mathrm{k}=0$ terus saya masukkan kepersamaan itu. Untuk $\mathrm{k}=0$ maka $\mathrm{x}$ nya 0 , untuk $\mathrm{k}=1$ maka $\mathrm{x}$ nya 72 , untuk $\mathrm{k}=2$ maka $\mathrm{x}$ nya 144 , untuk $\mathrm{k}=3$ maka $\mathrm{x}$ nya 216 , untuk $\mathrm{k}=4$ maka $\mathrm{x}$ nya 288 , untuk $\mathrm{k}=5$ maka $\mathrm{x}$ nya 360 .
PN1033S2 : Apakah tidak boleh nilai $\mathrm{x}$ nya negatif?
ST1034S2 : Tidak kak. Kan syaratnya $0 \leq x \leq 360$.
PN1037S2 : Jadi, apa himpunan penyelesaiannya?
ST1038S2 : Himpunan penyelesaiannya 0, 72, 144, 216, 288, dengan 360.

Berdasarkan hasil wawancara, ST mampu menjelaskan secara lisan hal yang diketahui dan ditanyakan pada soal. ST menjelaskan bahwa untuk menyelesaikan persamaan trigonometri bentuk $\tan x=$ a harus diubah terlebih dahulu kepersamaan trigonometri bentuk $\tan x=\tan \alpha$. Selanjutnya, dari hasil wawancara dengan ST diperoleh informasi bahwa ST menyelesaikan soal dengan menentukan nilai $\alpha$ dari persamaan $\tan 5 x=\tan 0$. Kemudian ST mensubstitusi nilai $\alpha$ kerumus $x=\alpha+k$. 360 sehingga diperoleh $5 x=0+k$. 360. Kemudian ST membagi masing-masing ruas dengan 5 sehingga diperoleh $x=0+k .72$ (ST05S2). ST salah dalam menentukan rumus yang digunakan untuk memperoleh penyelesaian persamaan $\tan x=\tan \alpha$. Kesalahan tersebut termasuk dalam kategori kesalahan prosedur tidak tepat (IP). Berdasarkan hasil wawancara, ST menjelaskan alasan memilih $\mathrm{k}$ untuk disubstitusi kerumus yaitu memilih nilai $\mathrm{k}$ yang jika disubstitusi kerumus memenuhi syarat $0 \leq x \leq 360$. Selanjutnya, ST menentukan himpunan penyelesaiannya yaitu $\{0,72,144,216,288,360\}$. 
Hasil tes tertulis ST dalam menyelesaikan S3 dipaparkan sebagaimana Gambar 3:

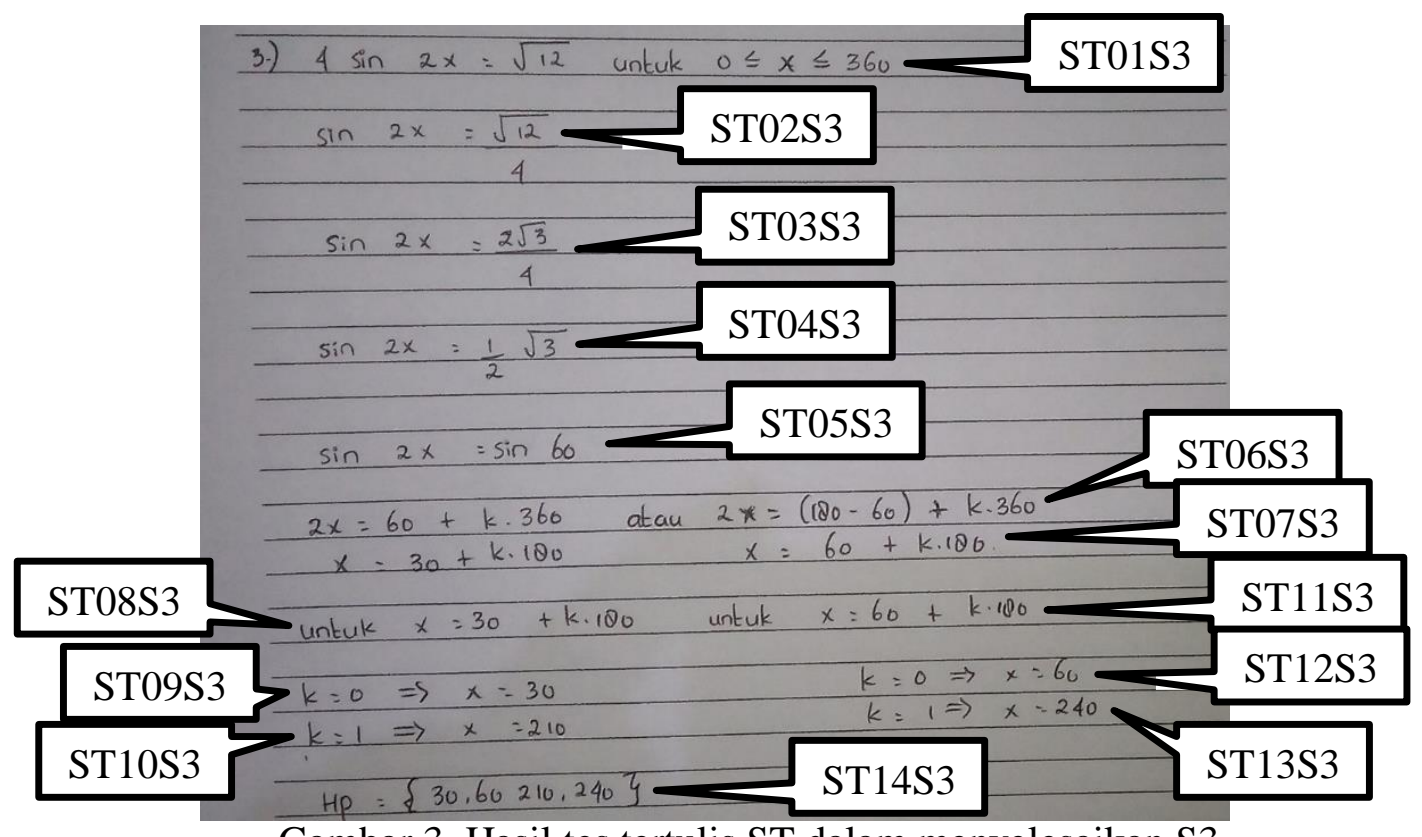

Gambar 3. Hasil tes tertulis ST dalam menyelesaikan S3

Penyelesaian ST terhadap S3 dapat dilihat sebagaimana Gambar 3. Peneliti melakukan wawancara dengan ST untuk memperoleh informasi lebih lanjut mengenai penyelesaian ST pada S3. Adapun petikan wawancara sebagai berikut:

PN1003S3 : Kemudian bagaimana cara ade menyelesaikannya?

ST1004S3 : Pertama saya tulis dulu yang diketahuinya $4 \sin 2 x=\sqrt{12}$, untuk $0 \leq x \leq 360$.

PN1005S3 : Setelah itu?

ST1006S3 : Saya bagi 4 kak persamaan $4 \sin 2 x=\sqrt{12}$

ST1008S3 : Supaya jadi ke bentuk persamaan $\sin \mathrm{x}=$ a kak.

ST1010S3 : Setelah itu $\sqrt{12}$ saya ubah jadi $2 \sqrt{3} \mathrm{kak}$

PN1013S3 : Kemudian jika sudah sederhana apa langkah selanjutnya?

ST1014S3 : Kan sudah saya peroleh sebelah kanannya itu. Nah̄ saya ubah itu jadi $\sin 60$.

ST1016S3 : Yang kak saya ubah jadi sin 60, sama seperti nomor 1 dengan 2. 
PN1017S3 : Dari mana didapat $\sin 60=\frac{1}{2} \sqrt{3}$ ?

ST1018S3 : Dari nilai sudut istimewa kak.

PN1019S3 : Setelah diperoleh $\sin 2 \mathrm{x}=\sin 60$, apa langkah selanjutnya?

ST1020S3 : Selanjutnya didapat nilai $\alpha$ nya $60 \mathrm{kak}$, terus saya masukkan nilai $\alpha$ itu kerumus mencari nilai $\mathrm{x}$ untuk sin kak.

ST1022S3 : $\mathrm{x}=\alpha+\mathrm{k} 360$ atau $\mathrm{x}=(180-\alpha)+\mathrm{k} .360 \mathrm{kak}$.

PN1025S3 : Setelah itu, berapa hasilnya ketika nilai $\alpha$ ade substitusi kerumus?

ST1026S3 : Saya dapat hasilnya $2 x=60+k 360$ atau $2 x=(180-60)+k 360$. Terus kan persamaannya masih $2 x$ jadi saya bagi 2 masing-masing persamaannya. Jadi diperoleh $\mathrm{x}=30+\mathrm{k} .180$ atau $\mathrm{x}=60+\mathrm{k} .180$.

ST1028S3 : Selanjutnya saya selesaikan yang $\mathrm{x}=30+\mathrm{k} .180 \mathrm{kak}$, saya misalkan $\mathrm{k}=0$ diperoleh $\mathrm{x}$ nya 30 . Kemudian saya misalkan $\mathrm{k}=1$ diperoleh $\mathrm{x}$ nya 210.

PN1031S3 : Setelah itu, apakah sudah didapat himpunan penyelesaiannya?

ST1032S3 : Belum kak. Setelah itu diselesaikan lagi persamaan $\mathrm{x}=60+\mathrm{k} .180 \mathrm{kak}$.

PN1033S3 : Bagaimana cara menyelesaikannya?

ST1034S3 : Saya misalkan lagi $\mathrm{k}=0$ diperoleh $\mathrm{x}$ nya 60. Kemudian saya misalkan $\mathrm{k}=1$ diperoleh x nya 240 .

PN1037S3 : Apa himpunan penyelesaiannya?

ST1038S3 : Himpunan penyelesaiannya 30, 60, 210 dan 240 kak.

Berdasarkan hasil wawancara, ST mampu menjelaskan yang diketahui dan ditanyakan pada soal. ST membagi masing-masing ruas dengan 4 agar persamaan tersebut menjadi persamaan trigonometri bentuk $\sin \mathrm{x}=\mathrm{a}$. Selanjutnya ST mengubah $\sqrt{12}$ menjadi $2 \sqrt{3}$ dan membagi pembilang dan penyebut dengan 2 sehingga diperoleh $\sin 2 x=\frac{1}{2} \sqrt{3}$ (ST04S3). Kemudian ST mengubah ruas kanan yaitu $\frac{1}{2} \sqrt{3}$ menjadi sin 60 . Berdasarkan hasil wawancara, ST menjelaskan bahwa untuk menyelesaikan persamaan bentuk $\sin \mathrm{x}=\mathrm{a}$ makapersamaan tersebut harus diubah kebentuk persamaan $\sin \mathrm{x}=\sin \alpha$.

ST menjelaskan bahwa untuk menyelesaikan soal maka terlebih dahulu ditentukan nilai $\alpha$ dari persamaan $\sin 2 \mathrm{x}=\sin 60$. Setelah ditentukan nilai $\alpha$, maka nilai $\alpha$ disubstitusi kerumus $x=\alpha+k .360$ atau $x=(180-\alpha)+k$. 360. Sehingga diperoleh $2 x=60+k .360$ atau $2 x=(180-60)+k .360$ (ST06S3). ST kemudian menyederhanakan rumus dengan membagi masing-masing ruas dengan 2 sehingga diperoleh $x=30+k$. 180 atau $x=60+k .180$ (ST07S3). Berdasarkan hasil wawancara, ST mampu menjelaskan alasan memilih $\mathrm{k}=0$ dan $\mathrm{k}=1$ untuk disubstitusi kerumus yaitu ST memilih nilai $\mathrm{k}$ yang jika disubstitusi kerumus diperoleh nilai $0 \leq x \leq 360$. Selanjutnya, ST menentukan himpunan penyelesaian yaitu $\{30,60,210,240\}$.

\section{Analisis penyelesaian soal subjek berkemampuan matematika sedang}

Hasil tes tertulis SS dalam menyelesaikan S1 dipaparkan sebagaimana Gambar 4:

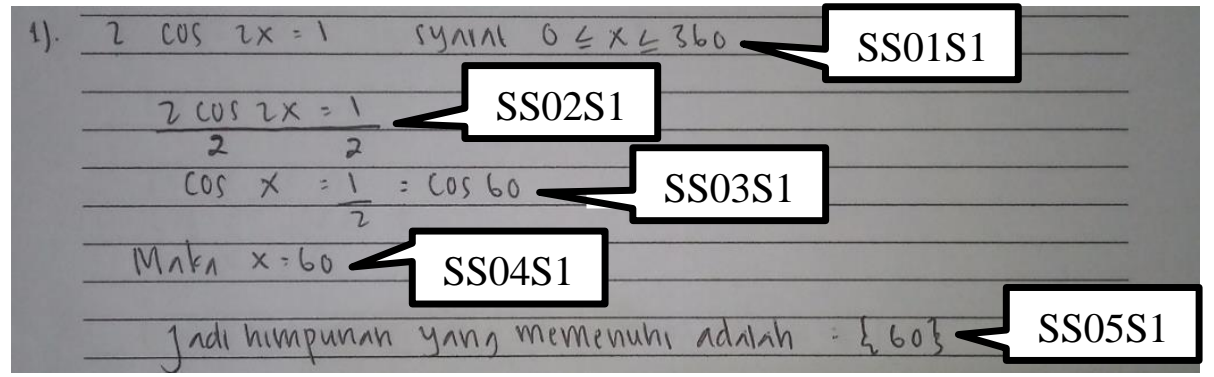

Gambar 4. Hasil tes tertulis SS dalam menyelesaikan S1 
Penyelesaian SS terhadap S1 dapat dilihat sebagaimana Gambar 4, SS menjawab soal dengan menuliskan $2 \cos 2 x=1$ syarat $0 \leq x \leq 360$ (SS01S1). Kemudian SS membagi masing-masing ruas dengan 2 sehingga diperoleh $\cos x=\frac{1}{2}$ dan mengubah $\frac{1}{2}$ menjadi $\cos 60$ (SS03S1). Dari persamaan $\cos x=\cos 60$, SS memperoleh nilai $\mathrm{x}=60$ (SS04S1). Kemudian SS menuliskan himpunan yang memenuhi adalah $\{60\}$ (SS05S1).

Peneliti melakukan wawancara dengan SS untuk memperoleh informasi lebih lanjut mengenai jawaban SS dalam menyelesaikan S1. Adapun petikan wawancara sebagaimana transkip berikut:

PN1005S1 : Apa saja informasi yang ade dapatkan dari soal?

SS1006S1 : Persamaan $2 \cos 2 x=1$, syaratnya $0 \leq x \leq 360$. Yang ditanyakan penyelesaiannya.

PN1009S1 : Coba ade jelaskan bagaimana cara menyelesaikannya?

SS1010S1 : Persamaannya langsung saya bagi 2 kak.

PN1011S1 : Kenapa dibagi 2?

SS1012S1 : Saya mau sederhanakan 2x nya kak supaya tinggal $\mathrm{x}$

SS1014S1 : 2 dibagi 2 kan 1 kak. terus $\cos 2 x$ itu $2 x$ nya saya bagi 2 hasilnya cos $\mathrm{x}$.

PN1017S1 : Jadi berapa hasil pembagiannya?

SS1018S1: $\cos x=\frac{1}{2} \mathrm{kak}$

SS1020S1 : Terus ruas kanan yang $\frac{1}{2}$ itu saya ubah jadi cos 60 kak.

SS1022S1 : Supaya kanan dan kiri sama-sama cos kak.

PN1023S1 : Kenapa disamakan?

SS1024S1 : Supaya bisa didapat nilai x nya kalau sudah sama kak.

PN1025S1 : Tapi kenapa $\frac{1}{2}$ diubah jadi cos 60 ?

SS1026S1 : Kan sama kak. $\frac{1}{2}=\cos 60$.

PN1027S1 : Dari mana diperoleh $\frac{1}{2}=\cos 60$ ?

SS1028S1 : Dari sudut istimewa itu kak.

PN1029S1 : Oh. Setelah itu, apa langkah selanjutnya?

SS1032S1 : Kan $\cos x=\cos 60$ kak. Berarti $x$ nya 60 karena kanan dan kirinya sama-sama cos.

PN1037S1 : Oh ok lanjut. Jadi kalau sudah didapat nilai $x$ nya, apakah sudah didapat himpunan penyelesaiannya?

SS1038S1 : Iya kak. Himpunan yang memenuhi itu 60

Adapun hasil wawancara menunjukkan bahwa SS mampu menjelaskan secara lisan hal yang diketahui dan ditanyakan pada soal. Sehingga dapat dikatakan SS mampu memahami masalah yang disajikan pada soal. SS membagi masing-masing ruas untuk menyederhanakan $\cos 2 \mathrm{x}$ menjadi $\cos \mathrm{x}$. Namun dalam melakukan pembagian, SS melakukan kesalahan karena pada saat melakukan pembagian koefisien, SS juga melakukan pembagian pada sudutnya. Selanjutnya SS mengubah ruas kanan pada persamaan yaitu $\frac{1}{2}$ menjadi cos 60 . Berdasarkan hasil wawancara, SS mengubah $\frac{1}{2}$ menjadi $\cos 60$ dikarenakan nilai dari $\frac{1}{2}=\cos 60$.

Setelah memperoleh persamaan $\cos x=\cos 60$, SS menentukan nilai $x=60$. Berdasarkan hasil wawancara, SS menentukan nilai $\mathrm{x}=60$ dikarenakan kedua ruas telah sama yaitu cosinus sehingga langsung dapat ditentukan nilai x. SS melakukan kesalahan dalam menentukan nilai $\mathrm{x}$ dikarenakan langsung menentukan nilai x dari persamaan trigonometri bentuk $\cos x=\cos \alpha$ tanpa menggunakan rumus $x=\alpha+k .360$ atau $x=-\alpha+k$. 360. SS menganggap jika persamaannya sudah berbentuk $\cos x=\cos \alpha$ maka $x=\alpha$. Kemudian, SS menentukan himpunan penyelesaiannya yaitu 60. 
Hasil tes tertulis SS dalam menyelesaikan S2 dipaparkan sebagaimana Gambar 5:

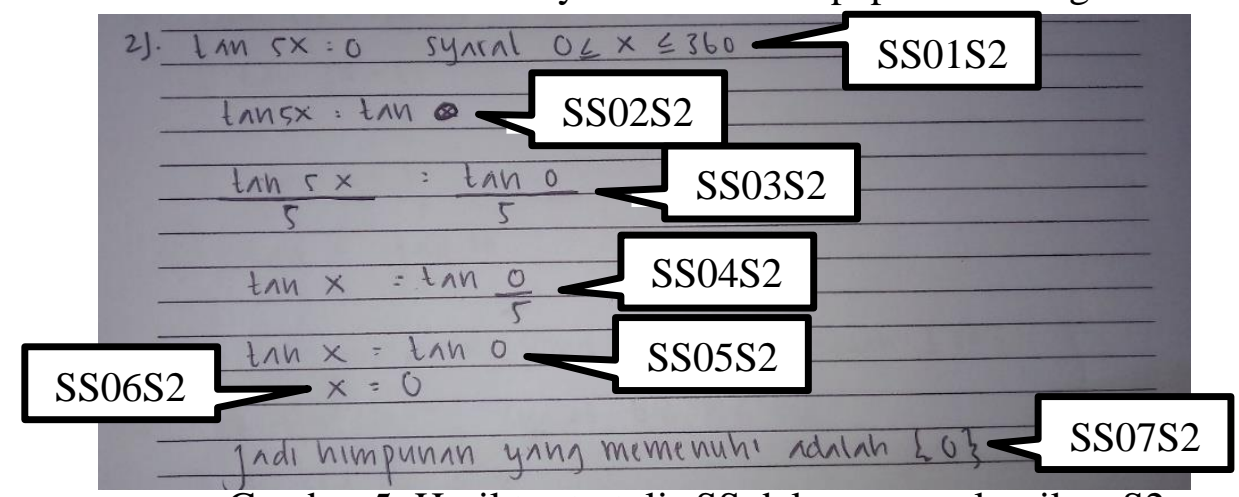

Gambar 5. Hasil tes tertulis SS dalam menyelesaikan S2

Penyelesaian SS terhadap S2 dapat dilihat sebagaimana Gambar 5. SS menjawab soal dengan menuliskan tan $5 x=0$ syarat $0 \leq x \leq 360$ (SS01S2). Kemudian SS mengubah ruas kanan persamaan yaitu 0 menjadi tan 0 sehingga diperoleh persamaan $\tan 5 x=\tan 0$ (SS02S2). SS membagi masing-masing ruas dengan 5 sehingga diperoleh $\tan x=\tan \frac{0}{5}$ (SS04S2). Kemudian SS membagi sudut dari tan pada ruas kanan yaitu ${ }_{5}^{0}$ hasilnya 0 sehingga persamaan menjadi $\tan x=\tan 0$ (SS05S2). Selanjutnya dari persamaan tersebut SS menentukan nilai $\mathrm{x}=0$ (SS06S2). Berdasarkan nilai $\mathrm{x}$ yang diperoleh maka SS menyimpulkan himpunan yang memenuhi adalah $\{0\}$ (SS07S2).

Peneliti melakukan wawancara dengan SS untuk memperoleh informasi lebih lanjut mengenai jawaban SS dalam menyelesaikan S2. Adapun petikan wawancara sebagaimana transkip berikut:

PN1005S2 : Apa saja informasi yang ade peroleh dari soal?

SS1006S2 : Persamaan tan $5 x=0$, syaratnya $0 \leq x \leq 360$. ditanyakan penyelesaiannya.

PN1009S2 : Ok. Coba jelaskan jawabannya ade.

SS1010S2 : Pertama sebelah kanannya saya ubah. 0 jadi tan 0

SS1012S2 : Supaya kanan dengan kirinya sama-sama tan kak

PN1013S2 : Kenapa kalau sudah sama-sama tan?

SS1014S2 : Kalau sudah sama kak sudah bisa ditentukan x nya.

PN1015S2 : Tapi kenapa 0 jadi tan 0?

SS1016S2 : Karena $0=\tan 0$ kak.

PN1017S2 : Dari mana ditau $0=\tan 0$ ?

ISS1018S2 : Dari nilai sudut istimewa kak.

PN1019S2 : Setelah itu, apa langkah selanjutnya?

SS1020S2 : Persamaannya langsung saya bagi 5.

SS1022S2 : Supaya sederhana kak. $5 x$ nya jadi $x$

PN1023S2 : Oh. Bagaimana caramu membagi dengan 5?

SS1024S2 : Kan $\frac{\tan 5 x}{5}$ jadi $5 x$ di bagi 5 jadi hasilnya $\tan x$. Terus $\frac{\tan 0}{5}=\tan 0.0$ dibagi 5 kan 0 kak jadi $\tan \frac{0}{5}=\tan 0$ kak.

PN1027S2 : Ok jadi berapa hasilnya?

SS1028S2 : $\tan \mathrm{x}=\tan 0$ kak.

PN1031S2 : Bagaimana cara mencari nilai $x$ nya?

SS1032S2 : Kan sebelah kanan dan kiri persamaanya sudah sama-sama tan kak. Jadibisa ditentukan nilai $\mathrm{x}$ nya.

PN1033S2 : Berapa nilai $x$ ?

SS1034S2 : $\mathrm{x}=0 \mathrm{kak}$.

PN1037S2 : Ok. Jadi setelah didapat nilai $\mathrm{x}$ nya, apa langkah selanjutnya? 
SS1038S2 : Menentukan himpunan yang memenuhi persamaannya kak. Yang saya dapat himpunan yang memenuhi itu adalah 0 .

Adapun hasil wawancara menunjukkan bahwa SS mampu menjelaskan secara lisan hal yang diketahui dan ditanyakan pada soal. SS mengubah 0 menjadi tan 0 agar kedua ruas menjadi tan. Selanjutnya SS membagi masing-masing ruas dengan 5. SS menjelaskan bahwa membagi persamaan $\tan 5 x=\tan 0$ dengan 5 untuk menyederhanakan tan $5 \mathrm{x}$ menjadi tan $\mathrm{x}$ sehingga mudah memperoleh nilai x. Tetapi dalam melakukan pembagian, SS melakukan kesalahan karena melakukan pembagian pada sudut dari tangen. Selanjutnya dari persamaan $\tan x=\tan$ 0 , SS memperoleh nilai $\mathrm{x}=0$. Dari hasil wawancara, SS menentukan nilai $\mathrm{x}=0$ dikarenakan kedua ruas pada persamaan telah sama sehingga dapat ditentukan nilai x nya. SS melakukan kesalahan dalam menentukan nilai x karena tidak menggunakan rumus $x=\alpha+k$. 180. SS menganggap bahwa jika persamaannya sudah berbentuk $\tan x=\tan \alpha$ maka $x=\alpha$. Kesalahan tersebut termasuk dalam kesalahan prosedur.

SS menentukan himpunan penyelesaian dari persamaan tan $5 \mathrm{x}=0$ yaitu 0 . Berdasarkan hasil wawancara, SS menjelaskan bahwa dalam menentukan himpunan penyelesaian yaitu dari nilai $\mathrm{x}$ yang diperoleh.

Hasil tes tertulis SS dalam menyelesaikan S3 dipaparkan sebagaimana Gambar 6:

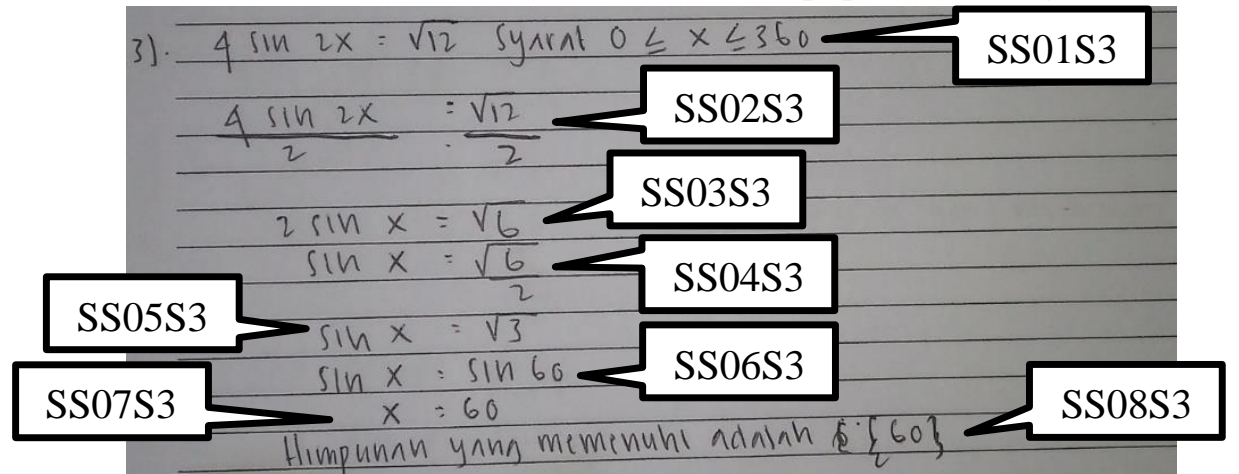

Gambar 6: Hasil tes tertulis SS dalam menyelesaikan S3

Penyelesaian SS terhadap S3 dapat dilihat sebagaimana Gambar 6, SS menjawab soal dengan menuliskan $4 \sin 2 x=\sqrt{12}$ syarat $0 \leq x \leq 360$ (SS01S3). Selanjutnya SS membagi masing-masing ruas dengan 2 (SS02S3) sehingga diperoleh $2 \sin x=\sqrt{6}$ (SS03S3). Kemudian SS membagi kedua ruas pada persamaan dengan 2 (SS04S3) sehingga diperoleh $\sin x=\sqrt{3}$ (SS05S3). Selanjutnya SS mengubah ruas kanan yaitu $\sqrt{3}$ menjadi sin 60 (SS06S3). Setelah diperoleh persamaan $\sin x=\sin 60$, SS memperoleh $\mathrm{x}=60$ (SS07S3) dan menyimpulkan himpunan yang memenuhi adalah $\{60\}$ (SS08S3).

Peneliti melakukan wawancara dengan SS untuk memperoleh informasi lebih lanjut mengenai jawaban SS dalam menyelesaikan S3. Adapun petikan wawancara sebagaimana transkip berikut:

PN1005S3 : Apa saja informasi yang ade peroleh dari soal?

SS1006S3 : Persamaan $4 \sin 2 x=\sqrt{12}$, syaratnya $0 \leq x \leq 360$. Ditanyakan himpunan penyelesaiannya.

PN1009S3 : Lanjut. Coba jelaskan jawabannya ade.

SS1010S3 : Pertama saya tulis ulang soalnya kak $4 \sin 2 x=\sqrt{12}$, syaratnya $0 \leq x \leq 360$

PN1011S3 : Coba jelaskan cara menyelesaikannya.

SS1012S3 : Persamaannya saya bagi dengan 2 kak.

SS1014S3 : Supaya 2x jadi x kak. Lebih sederhana dikerjakan.

PN1015S3 : Berapa hasil dari 4 sin $2 x$ di bagi 2?

SS1016S3 : 2 sin $\mathrm{x} \mathrm{kak}$ 
SS1018S3 : Kan sin 2x kak. berarti 2x nya dibagi 2 jadi hasilnya sin $\mathrm{x}$ kak.

PN1019S3 : Terus berapa hasilnya $\sqrt{12}$ dibagi 2 ?

SS1020S3 : $\sqrt{6} \mathrm{kak}$.

PN1021S3 : Bagaimana cara pembagiannya?

SS1022S3 : Langsung dibagi kak. $\sqrt{12}$ dibagi 2 hasilnya $\sqrt{6}$.

PN1023S3 : Oh. Coba jelaskan lagi langkah selanjutnya.

SS1024S3 : Setelah dibagi kan hasilnya $2 \sin x=\sqrt{6}$. Terus masing-masing ruas saya bagi 2 lagi kak supaya sebelah kirinya sisa $\sin \mathrm{x}$.

SS1030S3 : Setelah itu $\sqrt{3}$ saya ubah jadi sin 60

PN1031S3 : Kenapa $\sqrt{3}$ itu jadi sin 60 ?

SS1032S3 : Kan $\sqrt{3}=\sin 60$ kak.

PN1035S3 : Lanjut. Setelah ade peroleh $\sin \mathrm{x}=\sin 60$, apakah sudah bisa diperoleh nilai x nya?

SS1036S3 : Iya kak. Kan sudah sama-sama sin. Jadi didapat x nya 60

PN1039S3 : Setelah didapat nilai x nya, apa langkah selanjutnya?

SS1040S3 : Menentukan himpunan yang memenuhi persamaannya kak. Yang saya dapat himpunan yang memenuhi itu adalah 60 .

Adapun hasil wawancara menunjukkan bahwa SS mampu menjelaskan secara lisan hal yang diketahui dan ditanyakan pada soal. SS membagi persamaan dengan 2 agar $\sin 2 x$ menjadi sin $\mathrm{x}$ sehingga lebih sederhana dalam menentukan nilai $\mathrm{x}$. Selanjutnya SS menyederhanakan persamaan $2 \sin x=\sqrt{6}$ dengan membagi masing-masing ruas dengan 2. SS melakukan kesalahan dalam melakukan operasi pembagian dikarenakan membagi sudut dari sinus dengan penyebut. Kemudian SS juga melakukan kesalahan dalam membagi bilangan bentuk akar dengan bilangan bulat.

Selanjutnya, SS mengubah ruas kanan yaitu $\sqrt{3}$ menjadi sin 60 . Berdasarkan hasil wawancara, SS mengubah $\sqrt{3}$ menjadi sin 60 karena nilai $\sqrt{3}=\sin 60$. SS salah dalam mengubah bilangan menjadi bentuk trigonometri karena $\sqrt{3} \neq \sin 60$. Kemudian SS menentukan nilai $\mathrm{x}$ dari persamaan $\sin \mathrm{x}=\sin 60$ yaitu $\mathrm{x}=60$. Berdasakan hasil wawancara, SS langsung menentukan nilai $x$ karena kedua ruas sudah sama. SS melakukan kesalahan prosedur dikarenakan menentukan nilai $\mathrm{x}$ dari persamaan bentuk $\sin x=\sin \alpha$ tanpa menggunakan rumus $x=\alpha+k .360$ atau $x=(180-\alpha)+k$. 360. SS menganggap bahwa jika persamaannya sudah berbentuk $\tan x=\tan \alpha$ maka $x=\alpha$. SS menentukan himpunan penyelesaian dari persamaan $4 \sin 2 x=\sqrt{12}$ yaitu 60 . Berdasarkan hasil wawancara, SS menjelaskan bahwa dalam menentukan himpunan penyelesaian yaitu dari nilai $\mathrm{x}$ yang diperoleh. Namun, SS melakukan kesalahan prosedur dalam menentukan nilai x.

\section{Analisis penyelesaian soal subjek berkemampuan matematika rendah}

Hasil tes tertulis SR dalam menyelesaikan S1 dipaparkan sebagaimana Gambar 7:

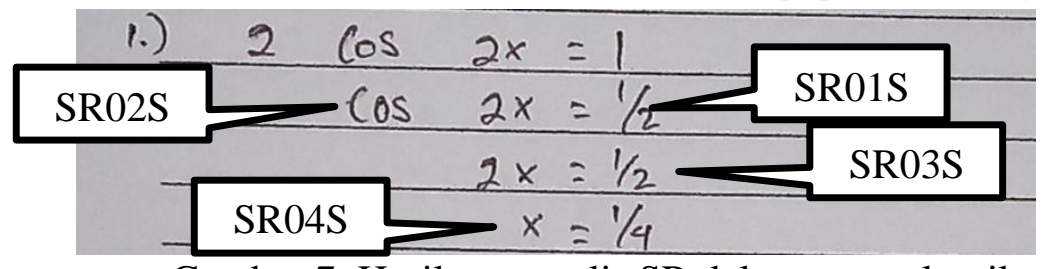

Gambar 7. Hasil tes tertulis SR dalam menyelesaikan S1

Penyelesaian SR terhadap S1 dapat dilihat sebagaimana Gambar 7. SR menjawab soal dengan menuliskan persamaan $2 \cos 2 x=1$ (SR01S1). Kemudian SR membagi ruas kanan 
dengan 2 sehingga diperoleh $\cos 2 x=\frac{1}{2}$ (SR02S1). Selanjutnya SR menyelesaian $2 x=\frac{1}{2}$ (SR03S1) dan SR memperoleh nilai $x=\frac{1}{4}(\mathrm{SR} 04 \mathrm{~S} 1)$.

Peneliti melakukan wawancara dengan SR untuk memperoleh informasi lebih lanjut mengenai jawaban SR dalam menyelesaikan S1. Adapun petikan wawancara sebagaimana transkip berikut:

PN1005S1 : Apa yang diketahui dan ditanyakan dari soal de?

SR1006S1 : Persamaan $2 \cos 2 x=1,0 \leq x \leq 360$. Yang ditanyakan himpunan penyelesaian.

PN1007S1 : Ok. Coba jelaskan jawabannya ade.

SR1008S1 : $2 \cos 2 \mathrm{x}=1$. Sebelah kanannya saya bagi 2 kak. Hasilnya $\cos 2 \mathrm{x}=\frac{1}{2}$.

PN1009S1 : Kenapa dibagi 2?

SR1010S1 : Supaya sebelah kirinya sisa $\cos 2 \mathrm{x}$.

PN1011S1 : Oh. Coba jelaskan langkah selanjutnya.

SR1012S1 : Kan yang dicari $\mathrm{x}$ nya kak. Saya selesaikan saja $2 \mathrm{x}=\frac{1}{2}$.

PN1013S1 : Ade tau dari mana yang dicari $x$ nya? cos nya kemana?

SR1014S1 : Dari soal kak. cos nya saya hilangkan.

PN1015S1 : Kenapa dihilangkan?

PN1016S1 : Karena saya tidak paham mau diapakan cos itu kak. jadi cuman saya selesaikan 2x saja

PN1019S1 : Ade tau rumus menyelesaikan atau mencari nilai $\mathrm{x}$ persamaaan trigonometri $\sin \mathrm{x}=\mathrm{a}$ ?

SR1020S1 : Hmmm. Lupa kak.

PN1021S1 : Ok. Lanjutkan penjelasan kelangkah berikutnya.

SR1022S1 : Setelah itu, sebelah kanan saya bagi 2 lagi. Saya dapat $\mathrm{x}=\frac{1}{4}$.

Berdasarkan hasil wawancara, SR dapat menjelaskan hal-hal yang diketahui pada soal namun keliru dalam memahami pertanyaan pada soal. SR memahami bahwa yang ditanyakan pada soal adalah nilai $\mathrm{x}$ padahal yang ditanyakan adalah himpunan penyelesaiannya. Selanjutnya SR menghilangkan cos pada persamaan sehingga diperoleh $2 x=\frac{1}{2}$ (SS03S1). SR menjelaskan bahwa cos dihilangkan karena yang dicari adalah nilai $\mathrm{x}$ sehingga yang diselesaikan yaitu $2 x$. Setelah diperoleh $2 x=\frac{1}{2}$, SR membagi ruas kanan dengan 2 sehingga diperoleh diperoleh $x=\frac{1}{4}$ (SS04S1). Dalam menyelesaikan soal, SR mampu menggunakan operasi pembagian dengan benar tetapi melakukan kesalahan prosedur dalam menentukan nilai $\mathrm{x}$ dari suatu persamaan trigonometri bentuk $\cos x=$ a sehingga penyelesaian menjadi salah.

Hasil tes tertulis SR dalam menyelesaikan S1 dipaparkan sebagaimana Gambar 8:

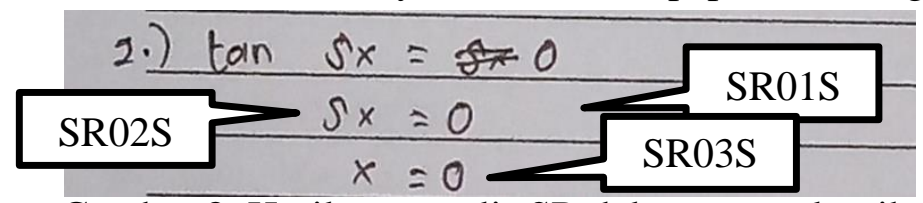

Gambar 8. Hasil tes tertulis SR dalam menyelesaikan S2

Penyelesaian SR terhadap S2 dapat dilihat sebagaimana Gambar 8, SR menjawab soal dengan menuliskan persamaan $\tan 5 x=0$ (SR01S2). Kemudian SR menyelesaikan 5x $=0$ (SR02S2) dan diperoleh hasil akhir $\mathrm{x}=0$ (SR03S2).

Peneliti melakukan wawancara dengan SR untuk memperoleh informasi lebih lanjut mengenai jawaban SR dalam menyelesaikan S2. Adapun petikan wawancara sebagaimana transkip berikut:

PN1005S2 : Apa yang diketahui dan ditanyakan dari soal? 
SR1006S2 : Persamaan tan $5 \mathrm{x}=0,0^{\circ} \leq x \leq 360^{\circ}$. Yang ditanya himpunan penyelesaiannya kak.

PN1007S2 : Coba jelaskan jawabannya ade.

SR1008S2 : Dari tan 5x $=0$. Yang saya selesaikan 5x $=0$ kak.

PN1009S2 : Kenapa hanya 5x? terus tan nya kemana?

SR1010S2 : Sama seperti nomor 1 kak. tan saya hilangkan kak. Hanya 5x yang saya selesaikan.

PN1017S2 : Kenapa tan dihilangkan?

PN1018S2 : Karena saya tidak paham bagaiamana menyelesaikan. Jadi hanya 5x nya saja saya selesaikan.

PN1013S2 : Ade tau rumus untuk menyelesaikan persamaan $\tan \mathrm{x}=\mathrm{a}$ ?

SR1014S2 : Lupa kak.

PN1015S2 : Ok. Coba jelaskan langkah selanjutnya.

SR1016S2 : Karena $5 \mathrm{x}=0$ berarti $\mathrm{x}=\frac{0}{5}=0$ kak.

Berdasarkan hasil wawancara, SR dapat menjelaskan hal-hal yang diketahui pada soal namun keliru dalam memahami pertanyaan pada soal. SR memahami bahwa yang ditanyakan pada soal adalah nilai x padahal yang ditanyakan adalah himpunan penyelesaiannya. Dari hasil wawancara dapat dikatakan bahwa kurangnya pemahaman SR dalam memaknai maksud dari soal.

SR menjelaskan bahwa tan dihilangkan karena yang dicari adalah nilai x sehingga yang diselesaikan yaitu $5 x$. Setelah diperoleh $5 x=0$, SS membagi kedua ruas dengan 5 sehingga diperoleh $x=0$ (SS03S2). Dalam menyelesaikan soal, SR mampu menggunakan operasi pembagian dengan benar tetapi melakukan kesalahan prosedur dalam menentukan nilai $\mathrm{x}$ dari suatu persamaan trigonometri bentuk $\tan p x=$ a sehingga penyelesaian menjadi salah.

Hasil tes tertulis SR dalam menyelesaikan S3 dipaparkan sebagaimana Gambar 9:

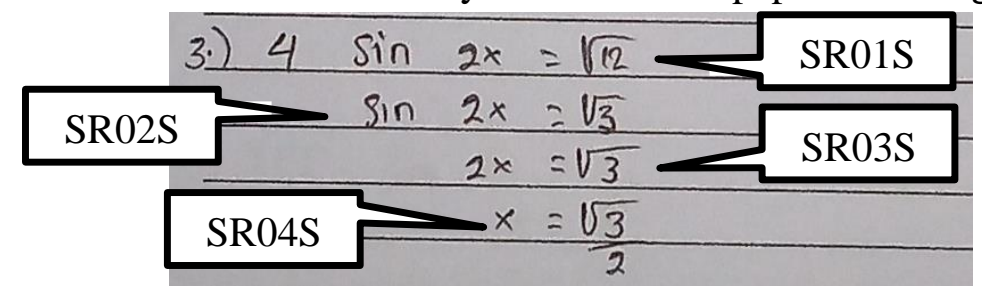

Gambar 9: Hasil tes tertulis SR dalam menyelesaikan S3

Penyelesaian SR terhadap S3 dapat dilihat sebagaimana Gambar 9. SR menjawab soal dengan menuliskan persamaan $4 \sin 2 x=\sqrt{12}$ ( $\overline{\mathrm{SR}} 01 \mathrm{~S} 3$ ). Kemudian SR membagi ruas kanan dengan 4 sehingga diperoleh $\sin 2 x=\sqrt{3}$ (SR02S3). Selanjutnya SR menyelesaikan $2 \mathrm{x}=\sqrt{3}(\mathrm{SR} 03 \mathrm{~S} 3)$ dan diperoleh hasil akhir $\mathrm{x}=\frac{\sqrt{3}^{3}}{2}(\mathrm{SR} 04 \mathrm{~S} 3)$.

Peneliti melakukan wawancara dengan SR untuk memperoleh informasi lebih lanjut mengenai jawaban SR dalam menyelesaikan S3. Adapun petikan wawancara sebagaimana transkip berikut:

PN1005S3 : Apa yang diketahui dan ditanyakan dari soal?

SR1006S3 : $4 \sin 2 x=\sqrt{12,0} \leq x \leq 360$. Ditanyakan nilai himpunan penyelesaiannya.

PN1007S3 : Coba jelaskan jawabannya ade.

SR1008S3 : $4 \sin 2 x=\sqrt{12}$, sebelah kanannya saya bagi 4 kak jadi didapat hasilnya $\sin 2 x$ $=\sqrt{3}$.

PN1009S3 : Kenapa dibagi 4 de?

SR1010S3 : Supaya sebelah kiri sisa sin 2x kak.

PN1011S3 : Kemudian diperoleh dari mana $\sqrt{3}$ ?

SR1012S3 : $\sqrt{12}$ dibagi 4 kak. 
PN1013S3 : Bagaimana cara pembagiannya?

SR1014S3 : Langsung dibagi kak $\sqrt{12}$ dibagi 4.

PN1019S3 : Ok. Coba jelaskan lagi langkah selanjutnya.

SR1020S3 : Kan sudah saya dapat $\sin 2 \mathrm{x}=\sqrt{3}$. Karena yang dicari nilai $\mathrm{x}$, jadi $2 \mathrm{x}=\sqrt{3}$.

PN1021S3 : Kenapa sin 2x jadi 2x saja?

SR1022S3 : Kan yang dibutuhkan $x$ nya saja kak. Jadi sin nya dihilangkan.

PN1023S3 : Kenapa tan dihilangkan?

PN1024S3 : Sama seperti tadi kak. Saya tidak terlalu paham kak. Jadi hanya 2x nya saja saya selesaikan.

PN1025S3 : Bukannya kalau menyelesaikan persamaan $\sin \mathrm{x}=\mathrm{a}$ harus gunakan rumus yah de?

SR1026S3 : Saya lupa yang mana rumusnya kak.

PN1027S3 : Ok lanjut lagi. Jelaskan langkah selanjutnya.

SR1028S3 : Setelah itu, sebelah kanan saya bagi dengan 2. Hasilnya $x=\frac{\sqrt{3}}{2}$

Berdasarkan hasil wawancara, SR dapat menjelaskan hal-hal yang diketahui pada soal namun keliru dalam memahami pertanyaan pada soal. SR memahami bahwa yang ditanyakan pada soal adalah nilai $\mathrm{x}$ padahal yang ditanyakan adalah himpunan penyelesaiannya. Selanjutnya, SR memisahkan sinus dan sudutnya dan menyelesaikan soal dengan menuliskan $2 x=\sqrt{3}$ (SS03S3). SR menjelaskan bahwa sin dihilangkan karena yang dicari adalah nilai $\mathrm{x}$ sehingga yang diselesaikan yaitu $2 \mathrm{x}$. Setelah diperoleh $2 x=\sqrt{3}$, SR membagi ruas kanan dengan 2 sehingga diperoleh diperoleh $x=\frac{\sqrt{3}^{3}}{2}$ (SS04S3). Dalam menyelesaikan soal, SR melakukan kesalahan dalam melakukan pembagian bilangan bentuk akar dengan bilangan bulat. Selain itu, SR melakukan kesalahan prosedur dalam menentukan nilai $\mathrm{x}$ dari suatu persamaan trigonometri bentuk $\sin x=$ a sehingga penyelesaian salah.

\section{PEMBAHASAN}

Berdasarkan analisis data hasil tes dan wawancara dalam menyelesaikan soal persamaan trigonometri, ST menuliskan dan menjelaskan informasi yang diperoleh dari soal berupa halhal yang diketahui dan ditanyakan dengan benar. Selanjutnya, ST menggunakan prosedur yang tepat dalam mengubah persamaan trigonometri. Kemudian ST mengaitkan konsep persamaan trigonometri dengan konsep lainnya yaitu nilai sudut istimewa. Selanjutnya ST menentukan nilai $\alpha$ dari suatu persamaan trigonometri dan disubstitusi kerumus. Ketika menentukan nilai $\mathrm{x}$, ST menggunakan operasi aljabar berupa perkalian, pembagian dan penjumlahan dengan benar. Pada langkah selanjutnya, ST mampu menentukan solusi dari persamaan trigonometri pada soal yang diberikan dengan memperhatikan syarat yang diberikan pada soal. Dari hasil wawancara, ST mampu menjelaskan alasan dari setiap langkah penyelesaian yang digunakan. Tetapi pada penyelesaian S2, ST melakukan kesalahan dalam menggunakan rumus untuk memperoleh penyelesaian persamaan trigonometri. Kesalahan ini disebut kesalahan prosedur tidak tepat (IP) menurut kriteria Watson.

Berdasarkan analisis data hasil tes dan wawancara dalam menyelesaikan soal persamaan trigonometri, SS menuliskan dan menjelaskan informasi yang diperoleh dari soal berupa halhal yang diketahui dan ditanyakan. Selanjutnya, SS menggunakan prosedur yang tepat dalam mengubah persamaan trigonometri. Kemudian SS mengaitkan konsep persamaan trigonometri dengan konsep lainnya yaitu nilai sudut istimewa. Setelah itu, SS langsung menentukan solusi dari persamaan trigonometri pada soal yang diberikan. Pada proses menyelesaikan soal, SS melakukan kesalahan dalam melakukan operasi pembagian dikarenakan melakukan pembagian pada sudut dari persamaan trigonometri serta salah dalam melakukan pembagian bilangan bentuk akar dengan bilangan bulat. Kesalahan ini disebut kesalahan hirarki keterampilan 
menurut kriteria Watson (SHP). Selain itu, SS melakukan kesalahan dalam menggunakan rumus untuk memperoleh penyelesaian persamaan trigonometri. Kesalahan ini disebut kesalahan prosedur tidak tepat (IP) menurut kriteria Watson. Pada penyelesaian S3, SS salah dalam mengubah nilai bilangan kebentuk trigonometri berdasarkan nilai dari sudut istimewa. Kesalahan ini disebut kesalahan data tidak tepat (ID) menurut kriteria Watson.

Berdasarkan analisis data hasil tes dan wawancara dalam menyelesaikan soal persamaan trigonometri, SR menuliskan dan menjelaskan informasi yang diperoleh dari soal. Selanjutnya, SR menggunakan operasi pembagian dengan benar mengubah persamaan trigonometri. Setelah itu, SR langsung menentukan nilai $x$ dari persamaan trigonometri pada soal yang diberikan tanpa menggunakan rumus. Pada proses menyelesaikan soal, SR melakukan kesalahan dalam melakukan operasi pembagian dikarenakan melakukan pembagian bilangan bentuk akar dengan bilangan bulat. Kesalahan ini disebut kesalahan hirarki keterampilan menurut kriteria Watson (SHP). Selain itu, SR melakukan kesalahan dalam menggunakan rumus untuk memperoleh penyelesaian persamaan trigonometri. Kesalahan ini disebut kesalahan prosedur tidak tepat (IP) menurut kriteria Watson. SR juga kurang memahami bentuk soal sehingga hanya mengoperasikan angka atau data yang ada tanpa ada alasan yang sesuai konsep trigonometri. Kesalahan ini disebut kesalahan konflik level respon (RLC) berdasarkan kriteria Watson. Selain itu, SR hanya menyelesaikan soal sampai pada menentukan nilai $\mathrm{x}$ tanpa menuliskan kesimpulan. Kesalahan ini disebut kesalahan kesimpulan hilang (OC) menurut kriteria Watson.

\section{KESIMPULAN}

Berdasarkan hasil penelitian dan pembahasan maka dapat diambil kesimpulan bahwa penyelesaian siswa kelas XI MIPA SMA Negeri 5 Model Palu yaitu: (1) Siswa berkemampuan matematika tinggi mampu menuliskan dan menjelaskan informasi yang diperoleh dari soal dengan benar, menggunakan prosedur yang tepat dalam mengubah persamaan trigonometri, mampu mengaitkan konsep persamaan trigonometri dengan konsep lainnya yaitu nilai sudut istimewa, menentukan nilai $\alpha$ dari suatu persamaan trigonometri dan disubstitusi kerumus, menggunakan operasi aljabar berupa perkalian, pembagian dan penjumlahan dengan benar dan mampu menentukan solusi dari persamaan trigonometri pada soal dengan memperhatikan syarat yang diberikan pada soal. Tetapi dalam menyelesaikan soal siswa masih melakukan kesalahan prosedur tidak tepat (IP). (2) Siswa berkemampuan matematika sedang mampu menuliskan dan menjelaskan informasi yang diperoleh dari soal, menggunakan prosedur yang tepat dalam mengubah persamaan trigonometri, mengaitkan konsep persamaan trigonometri dengan konsep lainnya yaitu nilai sudut istimewa. Tetapi pada proses penyelesaian soal, siswa melakukan kesalahan hirarki keterampilan (SHP), kesalahan prosedur tidak tepat (IP) dan kesalahan data tidak tepat (ID). (3) Siswa berkemampuan matematika rendah mampu menuliskan dan menjelaskan informasi yang diperoleh dari soal dan menggunakan prosedur yang tepat dalam mengubah persamaan trigonometri. Tetapi pada proses penyelesaian soal, siswa melakukan kesalahan hirarki keterampilan (SHP), kesalahan prosedur tidak tepat (IP), kesalahan konflik level respon (RLC) dan kesalahan kesimpulan hilang (OC).

\section{SARAN}

Berdasarkan pembahasan dan kesimpulan yang diperoleh, maka saran yang perlu disampaikan oleh peneliti yaitu guru sebaiknya lebih memperhatikan proses penyelesaian soal siswa, karena proses penyelesaian dibutuhkan untuk mengetahui pemahaman siswa terhadap suatu materi pembelajaran. Sehingga kendala yang dihadapi siswa dalam menyelesaikan soal dapat diketahui dan dijadikan bahan evaluasi guru untuk menentukan model dan strategi pembelajaran yang digunakan pada pembelajaran selanjutnya. 


\section{DAFTAR PUSTAKA}

Aisyah, F. N. (2019). Analisis kesalahan penyelesaian soal cerita berdasarkan kriteria Watson. [Online]. Tersedia: http://jurnalftk.uinsby.ac.id/index.php/jrpm/article/download/165/ 140. [04 November 2019]

Arikunto, S. (2013). Dasar-dasar Evaluasi Pendidikan. Jakarta: Bumi Aksara

Ibrahim. (2018). Metodologi Penelitian Kualitatif. Bandung: Alfabeta.

Kementerian Pendidikan dan Kebudayaan. (2016). Silabus Mata Pelajaran Matematika Sekolah Menengah Atas/Madrasah Aliyah/Sekolah Menengah Kejuruan/Madrasah Aliyah Kejuruan (SMA/MA/SMK/MAK). Jakarta: Kemendikbud.

Kementerian Pendidikan dan Kebudayaan. (2018). Kamus Besar Bahasa Indonesia. Jakarta: Adi Perkasa.

Kramarski, B \& Zoldan, S. (2008). Using Errors as Springboards for Enhancing Mathematical Reasoning With Three Metacognitive Approaches. The Journal of Educational Research. [Online]. Tersedia: https://www.tandfonline.com/doi/abs /10.3200/JOER.102.2.137-151. [14 Februari 2020].

Moleong, L. J. (2014). Metodologi Penelitian Kualitatif. Bandung: Remaja Rosdakarya.

Mulyani, M. \& Muhtadi, D. (2019). Analisis Kesalahan Siswa Dalam Menyelesaikan Soal

Trigonometri Tipe Higher Order Thinking Skill Ditinjau Dari Gender. Jurnal Penelitian Dan Pembelajaran Matematika, 12(1), 1-16. [Online]. Tersedia: https://doi.org/10.30870/ jppm.v12i1.4851. [04 Februari 2020]

Salim, P \& Salim, Y. (1991). Kamus Bahasa Indonesia Kontemporer. Jakarta: Modern English Press.

Saputri, R. (2018). Analisis Kesalahan Siswa dalam Menyelesaikan Soal Materi Fungsi Berdasarkan Kriteria Watson Ditinju Dari Perbedaan Gender Siswa SMP Kelas VIII. Jurnal Kadikma, 9(2), 59-68. [Online]. Tersedia: https://jurnal.unej.ac.id/ index.php/kadikma/article/view/9710/6367. [10 Februari 2020].

Sudarsono, Y. L. (2017). Diagnosis Kesulitan Belajar Siswa Kelas X MIA SMA Negeri 3 Magelang pada Pokok Bahasan Trigonometri Tahun Ajaran 2016/2017. [Online]. Tersedia: $\quad$ http://people.usd.ac.id/ ydkristanto/index.php/tugas-akhir-mahasiswa/ sudarsono-2017. [10 Februari 2020].

Sugiyono. (2018). Metodologi Penelitian Kuantitatif, Kualitatif, dan R\&D. Bandung: Alfabeta.

Widdiharto, R. (2008). Diagnosis Kesulitan Belajar Matematika SMP dan Alternatif Proses Remedinya. Yogyakarta: Pusat Pengembangan dan Pemberdayaan Pendidik dan Tenaga Kependidikan Matematika.

Yuliana. (2018). Analisis Kesalahan Siswa dalam Menyelesaikan Soal Integral Fungsi Aljabar di MAN 2 Kota Palu. Tesis, Program Pascasarjana, Universitas Tadulako. Palu: Tidak Diterbitkan. 